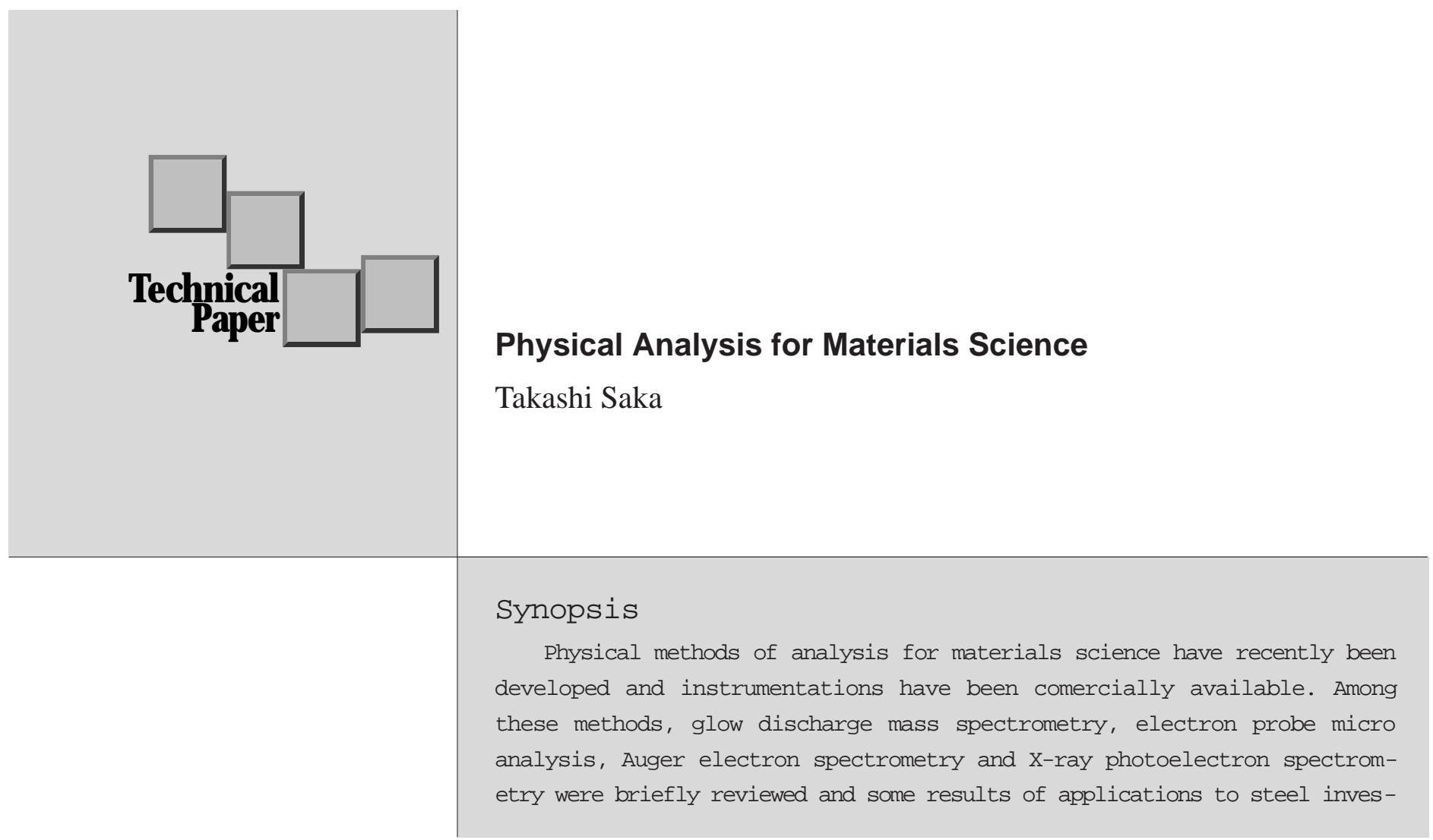

[ 1 . 緒言

物理分析という言葉は化学分析ほどポピュラーに使用 されないが，物理的手段によって物質の性質を調べる方 法を指す.具体的には質量分析,$X$ 線・粒子線分光分析 X線・粒子線回折などを指す .この方法の大きな特徵は ミクロの組成・結晶構造あるいは化学結合状態が観察で きることである，光の手法は一口で言えば，対象とする 物質にある刺激を与え，光れに対する反応を観測するこ とにより，上記特性を推測する．弚の原理はもともと科 学として研究対象となったものである. 兴の刺激を与え る通常の方法は粒子 (電子，イオン，光子など）を調へ る物質に照射し，光の粒子と物質の相互作用を利用する ことが多い . 探索の粒子をプローブと呼ぶ . プローブと して最も一般に普及しているのは電子線とX線であり， 電子線あるいはX線を入射し，これらと物質の相互作用 による入射電子線・X線の状態変化あるいは入射線によ って励起されるX線・粒子を調べる分析方法が用いられ
る . プローブと相互作用の組合わせにより多くの分析手 法が存在する . 当然のことながら , 分析方法の特徵はプ ローブと利用する相互作用の特徵で規定される．これら の特徵を理解した上で最も適した分析方法を選択するこ とが望まれる。

ここでは最近の物理分析技術の中で, 当社で広く利用 されている手法を中心に光の特徵・応用例を紹介すると 共に, 課題に対する最近の試みも記す。

\section{2. 質量分析法}

鉄鋼分析において，微量質量分析方法として早くから 利用されていたのはスパークイオン源質量分析 (Spark Source Mass Spectrometry;SSMS) 法である .この方法で はスパーク放電により発生した試料原子がスパークプラ ズマ中でイオン化され，質量分析計へ送られる．1960年 代の初頭より報告され始めた。しかし, 分析值の繰り返 し再現性 , 分析精度に難があることが指摘されている。 SSMSに代わり近年, 注目を集めているのがグロー放

1996年7月31日受付

* 大同特殊鋼（株）技術開発研究所，工博 (Dr., Eng., Research \& Development Lab., Daido Steel Co., Ltd.) 
電プラズマをイオン源にするグロー放電質量分析 (Glow Discharge Mass Spectrometry;GDMS) 法である . グ ロー放電は数T orrから数百T orrの減圧雰囲気で生成する 持続性の放電であり，支持ガスを必要とする．支持ガス としては通常Arを使用する.試料はグロー放電中のアル ゴンイオンによりスパッタされ, 負グローと呼ばれるプ ラズマ中でイオン化される .この方法はイオン源として 放電が安定であり，再現性が良いこと，また，次に述べ る二次イオン質量分析 (Secondary Ion Mass Spectrometry;SIMS) 法に比べて元素間の感度差が小さい ( 1 桁以内)，マトリックスによる感度の違いが小さいな どの利点を有し，また，質量分析法として，検出感度が 高く (ppbレベル), ダイナミックレンジが広い (〜9桁) 特徵を持つ，一方，限界として，非伝導性材料の直接測 定ができず，また，局所分析にも不向きである．GDMS はF.I.Scientific社（旧V.G.I sotopes社）よりV G9000の装置 が市販され，急速に普及している．当社でも1992年10月 に導入されて以来, 鉄鋼材料を中心に微量分析に利用さ れている

GDMSでは母材となる元素のイオン電流強度と目的と する元素のイオン電流強度の比より含有量を算出する その換算係数は相対感度係数 (Relative Sensitivity Factor;RSF) と呼ばれる．RSFは放電条件，試料形状に よって影響を受けるため，光れ光れの測定条件毎にRSF を算出することか望ましい，また，精度を必要とする場 合，母材による影響も考慮して各母材に対するRSFを調 べる必要がある。当社では導入以来，Fe基， $\mathrm{Ni}$ 基，Al基 およびTi基合金について多くの元素のRSFがピンおよび フラット試料に対して整備され, 精度の高い分析の提供 が可能となった . Fig.1にFe基， Ni基，Al基およびTi基 合金のピン型試料での含有量の範囲毎の平均の定量値の 相対誤差を示す．なお，測定条件を以下に示す.

支持ガス：超高純度Ar (99.9999\%以上)

放電電圧・電流 : $0.9 \mathrm{kV}, 2 \mathrm{~mA}$

加速電圧 : $7.8 \mathrm{kV}$

スキャンポイント : $60 \mathrm{ch} / ヒ^{\text {ス゚ク }}$

測定時間 : 160 200 msec/ch

質量分解能 : 4000

RSFの理解にはグロー放電でのイオン化機構の理解が 不可欠である . イオン化は次の 2 つ機構か関与すると 考えられている。

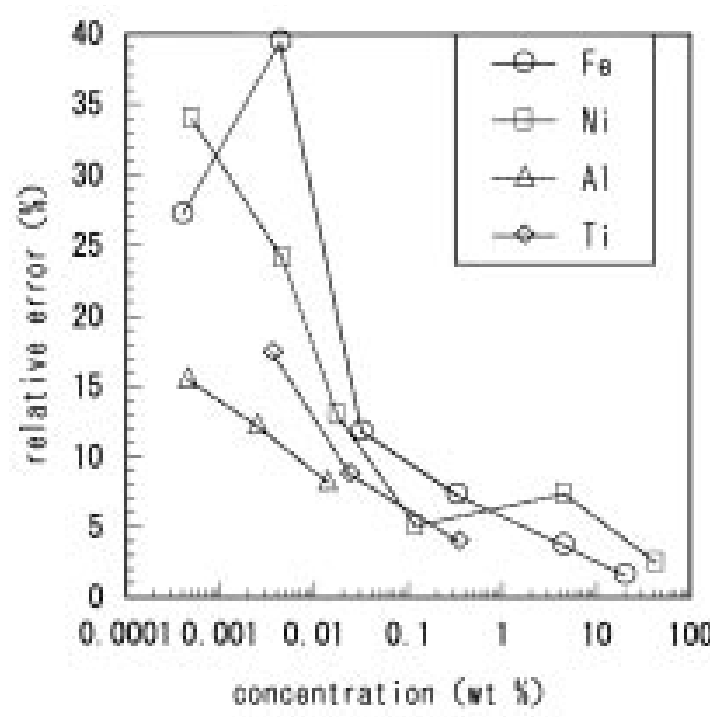

Fig. 1. Dependence of averaged relative error (magnitude) of analytical values by GDMS on concentration (wt: $)$.

$$
\begin{aligned}
& \mathrm{M}^{0}+\mathrm{e} \rightarrow \mathrm{M}^{+1}+2 \mathrm{e} \\
& \mathrm{M}^{0}+\mathrm{Ar}^{*} \rightarrow \mathrm{M}^{+1}+\mathrm{Ar}+\mathrm{e}
\end{aligned}
$$

ここで ${ }^{0}{ }^{0}$ は目的元素であり，Ar* ${ }^{*}$ は準安定状態のアルゴ ンを示す．前者は電子衝突イオン化, 後者はPenningイ オン化と呼ばれる .この 2 つの中でPenningイオン化が 大きな役割を果たすと考えられているが，まだ末解決の 部分が多い。また，イオンの取り出し効率もRSFに影響 を及ぼすと考えられている．当社の実験でも，ピン試料 とフラット試料でのRSFにFig.2に示す差異が認められ る .この現象はマトリックスおよび含有率に依らないこ とより，イオンの取り出し効率の差と考えられるが, 詳 しい検討は今後の課題である .

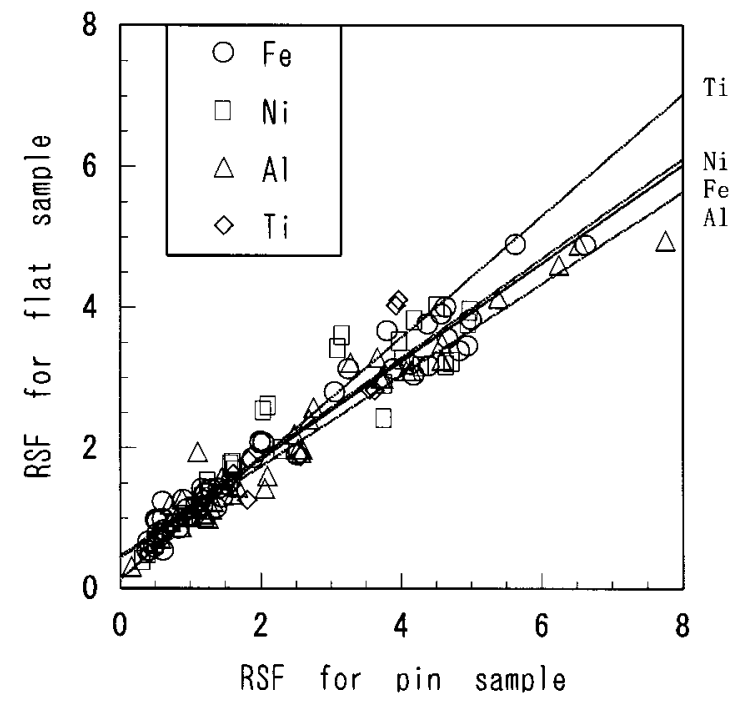

Fig. 2. Comparison of relative sensitivity factor (RSF; $\mathrm{Fe}=1$ ) for pin samples and flat samples. 
プラズマによる放電を用いない微量分析法で最も広く 用いられているのはSIMSである .この方法は ( 1 次) イオンを照射することによって生ずる2 次イオンを検出 する方法である . プローブとしてイオンビームを用いる ことにより局所分析が可能である．また，スパッタと分 析を繰り返すことにより，精度の高い深さ分布の測定も 可能であり，3 次元的評価に答えられる唯一の微量分析 法である.一方で，2次イオン収量（2次イオン数/1 次イオン数) が元素によって大きく異なり（5桁以上）, また , マトリックスにも依存する、鉄鋼材料には介在物 や酸化被膜が存在するが, これらの存在によって2 次イ オン収量か変化する『マトリックス効果』が問題となる． この課題を解決する方法としてスパッタ中性粒子質量分 析 (Sputtered Neutral Mass Spectrometry;SNMS) 法が検討 されている．この方法はイオン照射によりスパッタ放出 された中性粒子をイオン (ポストイオン) 化することに より分析を行う . ポストイオン化の手段としてプラズ マ・電子線・レーザを用いる方法が検討されている、特 にプラズマを用いる方法は基本的にGDMSと同じ原理て あり，プラズマ中のイオンの挙動を理解する上で共通す る部分が多く，今後の発展が期待される.

\section{[3.電子線プローブ分析法 ]}

電子は電荷を有することにより，容易に電場および磁 場により，㫕のエネルギー・方向を制御することが可能 である .このため , 古くからプローブとして用いられて きた．代表的な適用は電子顕微鏡である．この中で透過
型電子顕微鏡は入射電子の材料内の周期電場による回 折・散乱を利用するものであり，走査型電子顕微鏡は入 射電子による反射電子あるいは 2 次電子による表面観察 法である。

一方，電子により物質内の原子が励起され，安定状態 に遷移する際に放出される特性 X線やオージェ電子を観 測するのが電子線プローブマイクロ分析 (Electron Probe Micro A nalysis;EPMA，あるいはX線マイクロ分析X-ray Micro A nalysis;X MA とも呼ばれる) 法およびオージェ電 子分光 (A uger Electron Spectrometry;AES) 法である . こ の特性X線の波長およびオージェ電子の運動エネルギー は元素に固有であり, 元素の同定・分布を調べることが 可能である.最近, 当社に新しい装置か導入されたこと もあり，これら 2 方法について述べる .

3.1 電子線プローブマイクロ分析

装置は日本電子社製JX A - 8900RLである，電子銃とし てWおよびL B ${ }_{6}$ が使用可能であるが，通常Wを使用す る. 分析の空間分解能は入射電子のビーム径および電子 の材料内での広がりで決まる．X線を発生させる領域の 深さZmはCastaingの下式により評価できる .

$$
\mathrm{Zm}(\mu \mathrm{m})=\frac{0.033\left(\mathrm{~V}^{1 \cdot 7^{7}}-\mathrm{V}_{0}{ }^{1 \cdot{ }^{7}}\right) \mathrm{A}}{\rho \mathrm{z}}
$$

ここでVは加速電圧 $(k V) ， V_{0}$ は分析元素の特性 $X$ 線を発 生させる臨界電圧 $(k V) ， A ， \rho ， z は$ 光れ光れ分析試料の 平均の原子量, 密度, 原子番号である. 横への広がりは 入射電子のビーム径をdとした場合，Zm+dで与えられる Table 1に分析領域の主成分がFeの場合について，主な

Table 1. Dependence of analyzed depth $\mathrm{Zm}(\mu \mathrm{m})$ on accelerating voltage (kV) for some (trace) elements in Fe.

\begin{tabular}{|c|c|c|c|c|c|c|c|c|c|}
\hline \multirow{2}{*}{\multicolumn{2}{|c|}{$\frac{\text { Voltage }}{\text { Observed X-ray }}$}} & \multicolumn{2}{|c|}{5} & \multicolumn{2}{|c|}{10} & \multicolumn{2}{|c|}{20} & \multicolumn{2}{|c|}{30} \\
\hline & & $\mathrm{K} \alpha$ & $L \alpha$ & $\mathrm{K} \alpha$ & $L \alpha$ & $\mathrm{K} \alpha$ & $L \alpha$ & $\mathrm{K} \alpha$ & $L \alpha$ \\
\hline \multirow{3}{*}{$E$} & ${ }^{5} \mathrm{~B}$ & 0.14 & & 0.45 & & 1.47 & & 2.93 & \\
\hline & ${ }^{8} \mathrm{O}$ & 0.14 & & 0.45 & & 1.47 & & 2.92 & \\
\hline & ${ }^{15} \mathrm{P}$ & 0.11 & & 0.42 & & 1.44 & & 2.89 & \\
\hline \multirow[t]{2}{*}{ L } & ${ }^{20} \mathrm{Ca}$ & 0.04 & & 0.36 & & 1.37 & & 2.83 & \\
\hline & $25 \mathrm{Mn}$ & & & 0.23 & & 1.25 & & 2.71 & \\
\hline \multirow[t]{2}{*}{$E$} & ${ }^{30} \mathrm{Zn}$ & & 0.13 & 0.03 & 0.44 & 1.04 & 1.46 & 2.56 & 2.91 \\
\hline & ${ }^{34} \mathrm{Se}$ & & 0.12 & & 0.43 & 0.79 & 1.45 & 2.25 & 2.90 \\
\hline \multirow[t]{2}{*}{$M$} & $40 \mathrm{Zr}$ & & 0.10 & & 0.41 & 0.24 & 1.43 & & 2.88 \\
\hline & ${ }^{46} \mathrm{Pd}$ & & 0.06 & & 0.37 & & 1.39 & & 2.84 \\
\hline \multirow[t]{2}{*}{$E$} & $50 \mathrm{Sn}$ & & 0.02 & & 0.34 & & 1.35 & & 1.35 \\
\hline & ${ }^{60} \mathrm{Nd}$ & & & & 0.20 & & 1.21 & & 1.21 \\
\hline \multirow[t]{2}{*}{$\mathrm{N}$} & ${ }^{70} \mathrm{Yb}$ & & & & & & 0.98 & & 0.98 \\
\hline & $80 \mathrm{Hg}$ & & & & & & 0.59 & & 0.59 \\
\hline $\mathrm{T}$ & $83 \mathrm{Bi}$ & & & & & & 0.42 & & 0.42 \\
\hline
\end{tabular}


元素のZmを示す. 分析元素の原子番号が小さい程,$Z m$ は大きく，加速電圧が高い程 $Z m$ は大きくなる．また， 主成分が軽いとZmは大きくなる。

定量精度については, 従来, EPMAの信頼性は低い ( 50\%の誤差) と見做されていたが, 近年, 補正係数 の理論的研究が進み, 光の定量精度は向上している.今 回，ステンレス鋼および構造用鋼を用い定量精度を確認 した .なお，含有元素量は化学分析により得られた値を 採用した . 測定条件および定量手順を以下に示す。

測定条件 加速電圧 : $20 \mathrm{kV}$

照射電流 : $5 \times 10^{-8} \mathrm{~A}$

ビーム径 : $50 \mu \mathrm{m} \varphi$

測定時間 : ピーク $50 \mathrm{sec}$

$$
\text { バックグランド(片側) } 25 \mathrm{sec}
$$

測定点 : ランダムに選んだ 5 点

定量手順 (1) 標準試料での強度を測定 (5点での測 定の平均を算出)

(2) 測定試料での強度を測定（5点での測 定の平均を算出)

（3）強度比よりZAF補正により，含有率 を算出

なお，ZAF補正とは，測定試料より得られた X 線強度と 標準試料である純粋元素あるいは単純組成の化合物から のX線強度比より，含有率を求める際に行う補正で以下 の3 種類の補正を行う.

・原子番号効果 (A tomic Number Effect：Z補正)

試料中で発生するX線の相対強度の原子番号依存性 を補正する 。

・吸収補正 (A bsorption Correction: A 補正)

試料内部で発生した X 線の試料中での吸収を補正す る。

・蛍光励起補正 (Fluorescence Effect : F補正)

制動放射により発生したエネルギーの高い連続X線 や他元素から発生した特性 X線により励起された X 線の 加算を補正する .

Fig.3に含有率と変動係数 (Coefficient of V ariation, c.v.と略す) の関係を示す .なお，今回用いた試料には， 元素の偏析が認められ, 変動の要因となるが, 偏析のあ る試料でも，プローブのビーム径を大きく取り(今回の 測定では50 $\mu \mathrm{m} \varphi$ ) , 測定回数を多くする (今回の測定 では5回) ことにより，高い再現性の分析が期待できる．

Fig.4は化学分析值とEPMA定量値の 2 次元プロットで

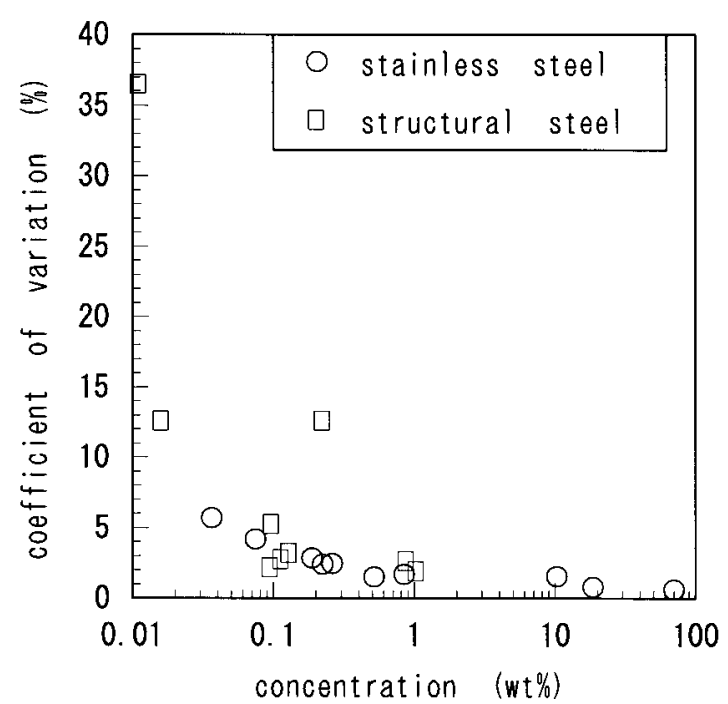

Fig. 3. Dependence of coefficient of variation (C.V.) on concentration (analyzed by EPMA, wt\%) .

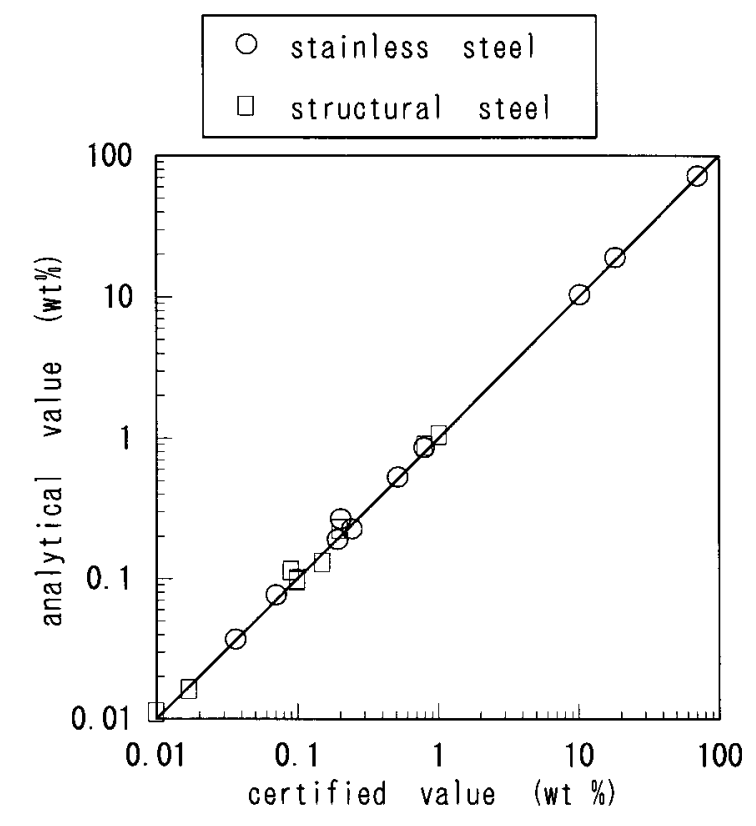

Fig. 4. Comparison of analytical values by EPMA and certified values (wt $\%$ ).

ある . ステンレス鋼ではほぼ10\%以内の，構造用鋼では ほぼ20\%以内の精度の定量值が得られた .これらに含ま れる19種の元素 (ステンレス鋼および構造用鋼で重複し て数える) の相対誤差 (絶対値) を, 含有率の範囲で区 分けして平均した値をTable 2に示す.

3.2 オージェ電子分光法

オージェ電子分光法は入射電子により発生するオージ エ電子のエネルギーより元素を同定する方法である．才 ージェ電子の強度は弱く，また，非弾性散乱電子による 
Table 2. Averaged relative error (magnitude) of analytical values by EPMA for different order of concentration .

\begin{tabular}{c|c}
\hline concentration(ppm) & relative error(\%) \\
\hline $100 \sim 1000$ & 9.1 \\
\hline $1000 \sim 10000$ & 9.1 \\
\hline$\geqq 10000$ & 1.4
\end{tabular}

バックグランドが大きいため, 定量精度および定量感度 はEPMAに比べて悪い，導入した装置はF.I.Instrument社 のMicrolab 310Fである.オージェ電子分光法の特徵は才 ージェ電子の脱出深さが浅い $(0.5 \sim 2.5 \mathrm{~nm})$ ため，極表 層の分析が可能である . また，オージェ電子の脱出深さ が浅いことは入射電子ビームの試料内での広がりの影響 がほとんどないことであり, 空間分解能が高い .さらに スパッタすることにより深さ分布の測定も可能であり 3 次元分解能の高い分析が行える.Fig.5 はSCr420 (0.10Nb添加) 鋼のNb析出物の形態を観察したものであ る.Nbと同時にCおよびNが観測され，Nb炭窒化物が確 認された．測定条件は加速電圧10kV，ビーム電流30nA

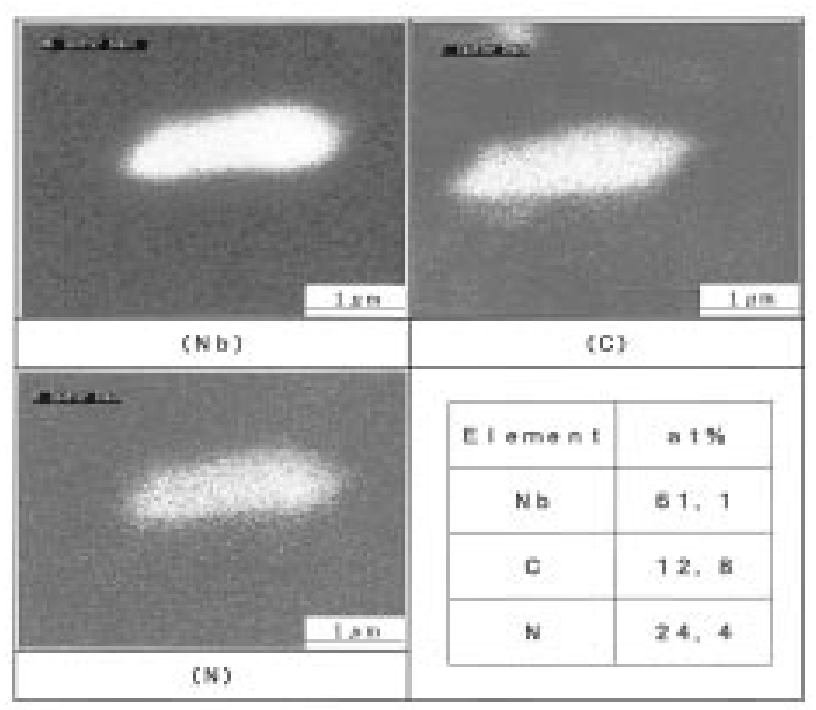

Fig. 5. Precipitate of No with $\mathrm{C}$ and $\mathrm{N}$ in $\mathrm{SCr} 420$ steel observed by AES.

であり，ビーム径は〜 70nmである . 空間分解能が高い ことより, 析出物の形状, Nbの分布も観測が可能であ る.

また，オージェ電子のスペクトルは午の化学結合状態 に依存し，スペクトルより，結合状態を推定することが 可能である . 特に, 結合状態により，スペクトルの位置 がずれる (ケミカル・シフトと呼ばれる) ことが一般に 利用されるが，乥れについては次の項で述べる．

\section{[ 4.X線プローブ分析法 $]$}

電子線でなく，X線をプローブとして用いる方法の代 表例力営光 $X$ 線分析法 (X-ray Fluorescence Analysis:XFA) である.关の方法はEPMAの電子プローブをX線に置き 換えたものであり，簡便であること，また絶绿物に対し ても適用可能であるが,空間分解能 (深さ方向も含めて) が悪いことより，局所分析には適さない．

もう 1 つの代表例が光電子分光 $(X$-ray Photoelectron Spectroscopy; XPS) 法”である。入射 X線（通常MgK a ；1253.8eVあるいはAIKa；1486.7eVが使用される) により励起された光電子のエネルギーより元素分析を行 う . 光電子の脱出深さもオージェ電子と同程度であり， 表面分析に適している.XPSでは原子の結合状態力变化 すると光電子スペクトルのケミカル・シフトや形状の変 化か観測され，化学状態を推測することが可能である。 FeとFeの化合物についてのFeのスペクトルを比較して Fig.6に示す . 化学結合によるスペクトルの変化はオー ジェ電子でも観測され，弚のケミカル・シフトは一般に オージェ電子の方が大きい, しかし，オージェ電子は关 の発生に関して3つの準位か関与するために解析が困難 であり，通常XPSが用いられる。最近，2次元の高分解 能の利点を生かして，AESによる化学状態の検討も行わ れており，今後の発展か望まれる。

*化学分析のための電子分光法 (Electron Spectroscopy for Chemical A nalysis:ESCA ) とも呼ばれる.

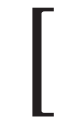

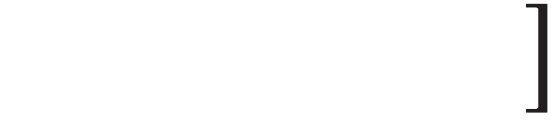

物理分析の中でグロー放電質量分析法, 電子線プロー ブマイクロ分析, オージェ電子分光法および光電子分光 法について产の特徵および応用例を示した .これらの分 析技術では一般に対象とする物質の構造についての知見 を得ることはできない . 物質の性質を調べる上で最も基 本である構造解析についてはX線回折・電子線回折法が 必要である .これらの技術は物理分析の中でも歴史が古 く( Laue et al.による結晶によるX線回折の発見は1912年， Davison \& Germerによる電子線回折の確認は1927年であ る)，解析方法もルーチンな作業については良く整備さ れているので省略した .さらに最近，走査型トンネル顕 


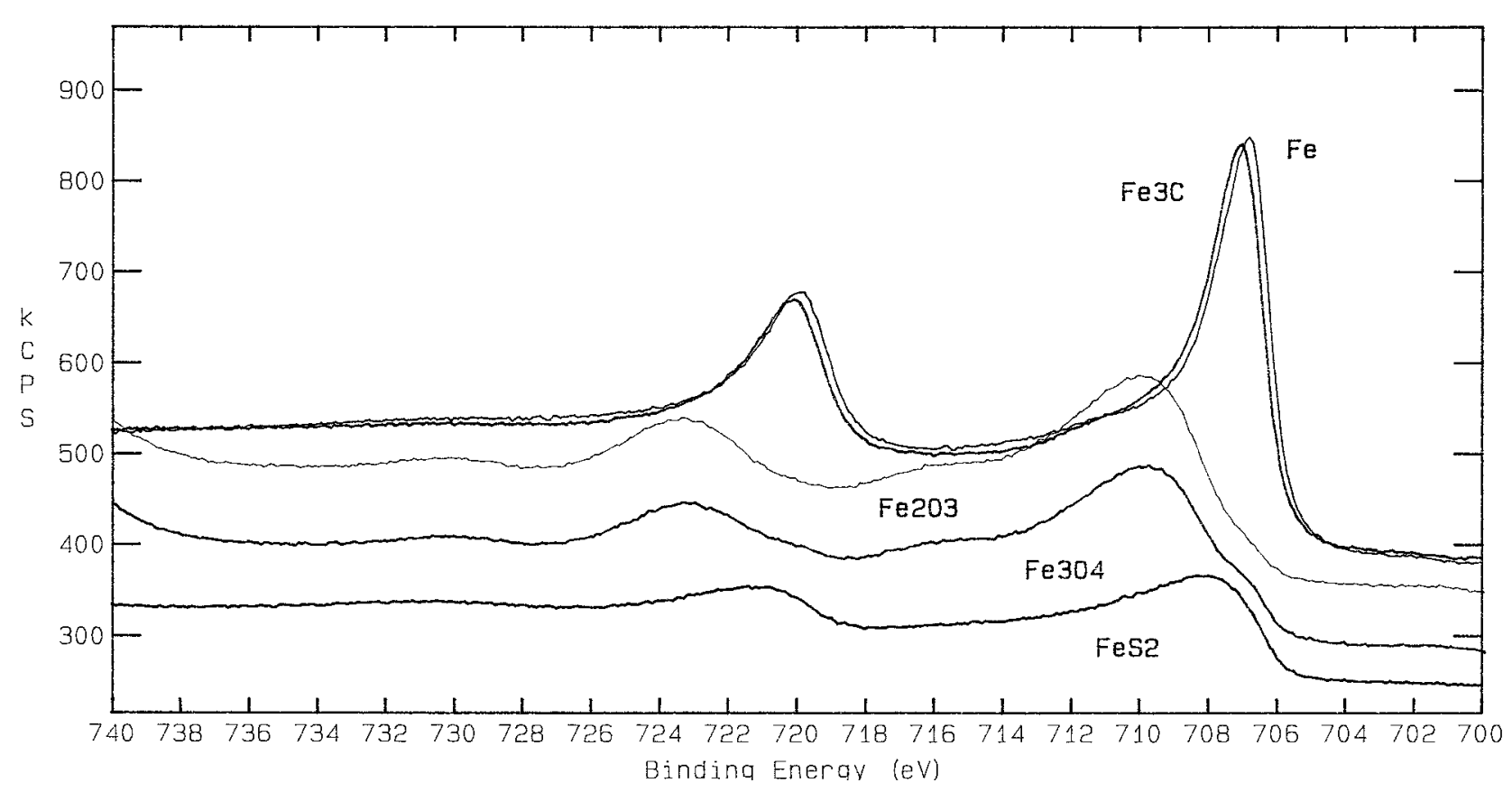

Fig. 6. X-ray photoelectron spectra of $\mathrm{Fe}$ and Fe compounds.

微鏡（Scanning Tunnel Microscopy:STM）および原子間力 顕微鏡法 (A tomic Force Microscopy:AFM) の発展が著し く，原子の配列が観察できるようになっている．今後， ナノスケールの材料開発にはこれらの技術が不可欠であ ると考えられが, 弚の基本的な原理は本稿で述べた手法 と異なるため, また，筆者の勉強不足のため，省略した． これらについては別の機会に触れたい .

最後に, 物理分析および表面分析についての解説の参 考文献を以下に記す．

(1) 日本学術振興会マイクロビームアナリシス第141委
員会編: マイクロビームアナリシス(1985)[朝倉書店 ] （2）志水隆一，吉原一紘編：ユーザーのための実用オー ジェ電子分光法 (1985) [共立出版]

(3) 内山 郁, 渡部 融, 紀本静雄: X線マイクロアナ ライザ(1972)［日刊工業新聞社］

(4) 堀内繁雄 : 高分解能電子顕微鏡 (1988) [共立出版]

（5）仁田勇監修：X線結晶学 (上),(下) (1959) [丸善]

（6）ブリッグス，シーア：表面分析 (上),(下) (1990) [アグネ承風社] 